\title{
General Anesthesia
}

\section{Propofol - not thiopental or etomidate - with remifentanil provides adequate intubating conditions in the absence of neuromuscular blockade}

\author{
[Le propofol, mais non le thiopental ou l'étomidate, combiné au rémifentanil, permet des \\ conditions d'intubation satisfaisantes en l'absence de blocage neuromusculaire]
}

Elvan Erhan MD, Gulden Ugur MD, Ilkben Gunusen MD, Isik Alper MD, Bulent Ozyar MD

\begin{abstract}
Purpose: Administration of remifentanil followed by propofol provides adequate conditions for tracheal intubation without muscle relaxants. Other hypnotic drugs have not been thoroughly investigated in this regard. Intubating conditions with remifentanil followed by propofol, thiopentone or etomidate are compared in this study.

Methods: In a randomized, double-blind study 45 healthy males were assigned to one of three groups $(n=15)$. After iv atropine, remifentanil $3 \mu \mathrm{g} \cdot \mathrm{kg}^{-1}$ were injected over $90 \mathrm{sec}$ followed by propofol $2 \mathrm{mg} \cdot \mathrm{kg}^{-1}$ (Group I), thiopentone $6 \mathrm{mg} \cdot \mathrm{kg}^{-1}$ (Group II) or etomidate $0.3 \mathrm{mg} \cdot \mathrm{kg}^{-1}$ (Group III). Ninety seconds after the administration of the hypnotic agent, laryngoscopy and intubation were attempted. Intubating conditions were assessed as excellent, good or poor on the basis of ease of ventilation, jaw relaxation, position of the vocal cords, and patient response to intubation and slow inflation of the endotracheal tube cuff.
\end{abstract}

Results: One patient in Group I, three patients in Group II and five patients in Group III could not be intubated on the first attempt. Clinically acceptable intubating conditions were observed in $93.3 \%$, $66.7 \%, 40.0 \%$ of patients in Groups I, II and III, respectively. Overall conditions at intubation were significantly $(P<0.05)$ better, and the frequency of excellent conditions was significantly $(P<$ 0.05) higher in the propofol group compared with the thiopentone and etomidate groups. No patient was treated for hypotension or bradycardia.

Conclusion: Propofol $2 \mathrm{mg} \cdot \mathrm{kg}^{-1}$ was superior to thiopentone 6 $\mathrm{mg} \cdot \mathrm{kg}^{-1}$ and etomidate $0.3 \mathrm{mg} \cdot \mathrm{kg}^{-1}$ for tracheal intubation when combined with remifentanil $3 \mu \mathrm{g} \cdot \mathrm{kg}^{-1}$ and no muscle relaxant.
Objectif : L'administration de rémifentanil suivie de propofol permet des conditions satisfaisantes d'intubation endotrachéale sans myorelaxants. D'autres hypnotiques n'ont pas encore été testés dans ces circonstances. Nous avons donc voulu comparé les conditions d'intubation avec le rémifentanil suivi du propofol, du thiopental ou de l'étomidate.

Méthode : L'étude randomisée et à double insu a été réalisée auprès de 45 hommes en bonne santé, répartis en trois groupes $(n=15)$. Après l'administration iv d'atropine, l'injection de $3 \mu \mathrm{g} \cdot \mathrm{kg}^{-1}$ de rémifentanil, pendant $90 \mathrm{sec}$, a été suivie de $2 \mathrm{mg} \cdot \mathrm{kg}^{-1}$ de propofol (Groupe I), de $6 \mathrm{mg} \cdot \mathrm{kg}^{-1}$ de thiopental (Groupe II) ou de 0,3 $\mathrm{mg} \cdot \mathrm{kg}^{-1}$ d'étomidate (Groupe III). Quatre-vingt-dix secondes après l'administration de l'agent hypnotique, la lanyngoscopie et l'intubation ont été tentées. Les conditions d'intubation ont été évaluées comme excellentes, bonnes ou pauvres d'après la facilité de ventilation, du relâchement de la mâchoire, la position des cordes vocales et la réponse du patient à l'intubation et au gonflement lent du ballonnet du tube endotrachéal.

Résultats : Un patient du Groupe I, trois du Groupe II et cina du Groupe III n'ont pu être intubés au premier essai. Des conditions d'intubation acceptables ont été observées chez 93,3\%, 66,7 \% et 40,0 $\%$ des patients des Groupes I, II et III. Dans l'ensemble, les conditions d'intubation ont été significativement $(P<0,05)$ meilleures, et la fréquence de conditions excellentes a été significativement $(P<0,05)$ plus élevée, avec le propofol, comparé au thiopental et à l'étomidate. Aucun patient n'a dû recevoir de traitement pour hypotension ou bradycardie.

Conclusion : Les conditions d'intubation endotrachéale ont été meilleures avec l'usage de $2 \mathrm{mg} \cdot \mathrm{kg}^{-1}$ de propofol, comparés à 6 $m g \cdot \mathrm{kg}^{-1}$ de thiopental et à 0,3 $\mathrm{mg} \cdot \mathrm{kg}^{-1}$ d'étomidate, combinés à 3 $\mu \mathrm{g} \cdot \mathrm{kg}^{-1}$ de rémifentanil et sans myorelaxants.

From the Department of Anesthesiology and Reanimation, Ege University, Faculty of Medicine, Izmir, Turkey.

Address correspondence to: Dr. Elvan Erhan, Mithatpasa cad. 959/3, 35290, Guzelyal, Izmir, Turkey. Phone: +90 5424143685 ;

Fax: +90 232 2479783; E-mail: elvanerhan@yahoo.com

Accepted for publication February 26, 2002.

Revision accepted September 6, 2002. 
A FTER induction of anesthesia, tracheal intubation is commonly facilitated by the use of muscle relaxants. Recent studies have suggested that propofol in combination with short-acting opioids such as alfentanil and remifentanil may provide adequate conditions for laryngoscopy and tracheal intubation without using muscle relaxants. ${ }^{1-6}$ Such a technique is of value in particular situations in which muscle relaxants have to be avoided (myopathies, known allergic reactions to muscle relaxants) or in cases where succinylcholine is contraindicated (hyperkalemia, burns, plasma cholinesterase deficiency, penetrating eye injury). It is also advantageous in cases where intubation is necessary but neuromuscular block is not required to facilitate surgical access. Avoiding muscle relaxants when they are not required for the planned procedure may prevent the potential complications of their use, misuse, and antagonism. Excessive or unnecessary neuromuscular blockade is one of the factors cited as contributing to awareness under general anesthesia. ${ }^{7}$ The administration of muscle relaxants during balanced anesthesia is often routine, although it is frequently unnecessary, and it removes important motor signs of awareness such as eye opening or movement. ${ }^{8}$ Limiting the use of muscle relaxants to appropriate indications should help prevent this adverse event. ${ }^{7}$

Remifentanil has unique properties and undergoes rapid hydrolysis by non-specific blood and tissue esterases. Although onset of effect is similar to that of alfentanil, within one to two minutes, it has a shorter half-life and the time to recovery is not greatly influenced by the dose. ${ }^{9,10}$ Those clinical properties make remifentanil the short-acting opioid of choice for circumstances in which an intense opioid effect of short duration is required. The most prominent effect of propofol is a decrease in arterial blood pressure during induction of anesthesia. ${ }^{11}$ The decrease in arterial pressure observed in previous studies ${ }^{1-6}$ in which propofol in combination with short-acting opioids was used to provide adequate conditions for laryngoscopy and tracheal intubation without using muscle relaxants might not be well tolerated in some less healthy patients. On the other hand etomidate in combination with shortacting opioids may have a better hemodynamic outcome in this clinical setting since the minimal effect of etomidate on cardiovascular function sets it apart from other fast acting induction agents. ${ }^{11}$

Using a randomized, double-blind study design we compared intubating conditions and cardiovascular responses to induction and endotracheal intubation in premedicated patients receiving remifentanil $3 \mu \mathrm{g} \cdot \mathrm{kg}^{-1}$ followed by propofol $2 \mathrm{mg} \cdot \mathrm{kg}^{-1}$, thiopentone 6 $\mathrm{mg} \cdot \mathrm{kg}^{-1}$, or etomidate $0.3 \mathrm{mg} \cdot \mathrm{kg}^{-1}$.

\section{Methods}

After obtaining approval from the Ethics Committee of the Ege University Hospital and informed written consent from patients, we studied 45 ASA I-II male patients, aged 15-60 yr undergoing general anesthesia and tracheal intubation for elective ambulatory urologic surgery. Exclusion criteria included history of drug or alcohol abuse, gastroesophageal reflux or hiatus hernia, cardiovascular disease, reactive airway disease, body mass index 30 or more, allergies to any of the study drugs, administration of sedative or narcotic drugs in the previous $24 \mathrm{hr}$, renal or hepatic impairment, or Mallampati classification of airway anatomy higher than II. ${ }^{12}$

Midazolam $0.03 \mathrm{mg} \cdot \mathrm{kg}^{-1}$ iv was given as premedication approximately five minutes before induction of anesthesia. All patients were prehydrated with saline $0.9 \% 7 \mathrm{~mL} \cdot \mathrm{kg}^{-1}$ before induction. Patients were randomized using a random number generator to one of three study groups to receive the following in a double-blind manner: remifentanil $3 \mu \mathrm{g} \cdot \mathrm{kg}^{-1}$ followed by propofol $2 \mathrm{mg} \cdot \mathrm{kg}^{-1}$ (Group I, $n=15$ ), thiopentone 6 $\mathrm{mg} \cdot \mathrm{kg}^{-1}$ (Group II, $n=15$ ), or etomidate $0.3 \mathrm{mg} \cdot \mathrm{kg}^{-1}$ (Group III, $n=15$ ). The induction sequence was conducted using two pre-prepared syringes. Syringe 1 contained remifentanil $3 \mu \mathrm{g} \cdot \mathrm{kg}^{-1}$ and was filled with saline to a volume of $9 \mathrm{~mL}$. Syringe 2 contained propofol $2 \mathrm{mg} \cdot \mathrm{kg}^{-1}$, thiopentone $6 \mathrm{mg} \cdot \mathrm{kg}^{-1}$, or etomidate $0.3 \mathrm{mg} \cdot \mathrm{kg}^{-1}$. Opaque tape was applied to syringe 2 to disguise the colour of the hypnotic drug. The coded test syringes were prepared by a nurse who did not take part in the study. Injection of all syringes was performed behind a drape so that all anesthesiologists were blinded to the hypnotic drug administered.

Baseline heart rate (HR) and mean arterial pressure (MAP) were recorded. After preoxygenation for two minutes, atropine $0.01 \mathrm{mg} \cdot \mathrm{kg}^{-1}$ was given intravenously to all patients. Then remifentanil $3 \mu \mathrm{g} \cdot \mathrm{kg}^{-1}$ was injected over $90 \mathrm{sec}$. Sixty seconds after beginning remifentanil, the hypnotic agent was given in over ten seconds. Once the patient became unconscious, as judged by loss of response to command and loss of eyelash reflex, mask ventilation was initiated. Fortyfive seconds after study drug administration, the patient's postinduction vital signs were recorded. Ninety seconds after hypnotic agent administration, laryngoscopy and intubation were attempted with a Macintosh 3 laryngoscope blade and an $8.0 \mathrm{~mm}$ endotracheal tube. Ease of mask ventilation, jaw relaxation, laryngoscopy, vocal cord position, and patient response to intubation (coughing, limb movement) and slow (five seconds) inflation of the endotracheal tube cuff were assessed by the intubating anesthesiol- 
TABLE I Intubating condition score

\begin{tabular}{lllll}
\hline & Score & & & \\
& 1 & 2 & 3 & 4 \\
\hline Mask ventilation & easy & difficult & impossible & -- \\
Jaw relaxation & complete & slight tone & stiff & rigid \\
Laryngoscopy & easy & fair & difficult & impossible \\
Vocal cord position & open & moving & closing & closed \\
Coughing & none & slight & moderate & severe \\
Limb movement & none & slight & moderate & severe \\
Cuff response & none & slight & moderate & severe \\
\hline
\end{tabular}

TABLE II Patient characteristics. The study drugs were given in combination with remifentanil $3 \mu \mathrm{g} \cdot \mathrm{kg}^{-1}$

\begin{tabular}{llll}
\hline Group $(n=15)$ & Age $(y r)$ & Weight $(\mathrm{kg})$ & Male / female \\
\hline $\begin{array}{l}\text { Group I } \\
\left.\text { (propofol 2 mg. } \cdot \mathrm{kg}^{-1}\right)\end{array}$ & $34.9 \pm 13.2$ & $72.0 \pm 15.8$ & $20 / 0$ \\
$\begin{array}{l}\text { Group II } \\
\left.\text { (thiopentone } 6 \mathrm{mg} \cdot \mathrm{kg}^{-1}\right)\end{array}$ & $34.0 \pm 9.7$ & $78.1 \pm 13.5$ & $20 / 0$ \\
$\begin{array}{l}\text { Group III } \\
\left(\text { etomidate } 0.3 \mathrm{mg} \cdot \mathrm{kg}^{-1}\right)\end{array}$ & $30.7 \pm 8.9$ & $76.5 \pm 12.3$ & $20 / 0$ \\
\hline
\end{tabular}

ogist. The various criteria used for intubating conditions are presented in Table I. These criteria were used to score overall conditions of intubation as excellent (all criteria scored as 1), good (mask ventilation scored as 1 , and the other criteria as 1 or 2 ) or poor (one of the criteria scored as 3 ). Patients who could not be intubated on the first attempt were given atracurium $0.5 \mathrm{mg} \cdot \mathrm{kg}^{-1}$ iv and intubation was completed. Adverse events such as laryngospasm, bronchospasm or chestwall rigidity, as indicated by difficulty to ventilate and the need for further drugs, were also recorded.

Monitors included an automated blood pressure cuff, electrocardiogram, peripheral pulse oximeter, and capnometer. Control values of arterial pressure, $\mathrm{HR}$, and peripheral oxygen saturation $\left(\mathrm{SpO}_{2}\right)$ were obtained before atropine (preinduction). Then, measurements were obtained $45 \mathrm{sec}$ after the bolus dose of hypnotic agent was given (postinduction), immediately after intubation (postintubation), and three and five minutes after intubation. Ephedrine $6 \mathrm{mg}$ was administered if MAP fell by more than $30 \%$ of baseline, and atropine $500 \mu \mathrm{g}$ was administered if the HR fell below 50 beats. $\mathrm{min}^{-1}$. Anesthesia was maintained with $0.5-1 \%$ isoflurane and $66 \%$ nitrous oxide in oxygen, and the lungs were ventilated to normocapnia. No further stimulation was applied to the patient during the study period.

\section{Statistical analysis}

One-way ANOVA (Post-hoc test/Bonferroni test) were used for the comparison of age and body weight between the three groups. Kruskal Wallis test (with between group comparisons performed using the Mann Whitney-U test with Bonferroni correction) was used to compare the scores of mask ventilation, jaw relaxation, laryngoscopy, vocal cords, coughing, limb movement, response to cuff inflation and overall intubating conditions between the three groups. Chi square test was used to compare the number of patients who could not be intubated on the first attempt between groups. For hemodynamic variables, repeated measures ANOVA was used according to the model of two factor experiment (group and time) with a repeated measure on one factor (time). If there was interaction between time and group, then for each group one factor (time) experiment model with a repeated measure ANOVA was used. When appropriate, the Bonferroni test was used as Post-hoc method. $P<0.05$ was considered significant.

\section{Results}

There were no demographic differences between the groups (Table II). The patients underwent ambulatory varicocele surgery. All patients could be ventilated via facemask after induction. However mask ventilation was judged to be difficult in three and four patients in the thiopentone and etomidate groups, respectively $(P=0.12)$. No other factors such as mask fit, dentition, etc., could explain difficulty with ventilation in these patients. Jaw relaxation was judged to be complete in $93.3 \%, 46.7 \%, 40.0 \%$ of patients in the propofol, thiopentone and etomidate groups, respectively $(P=0.005)$. Laryngoscopy was easy in $93.3 \%$, $80.0 \%, 73.3 \%$ of patients in the propofol, thiopentone and etomidate groups, respectively $(P=0.355)$. Because of closed vocal cords intubation was judged to be impossible in one, three and five patients in the propofol, thiopentone and etomidate groups, respectively $(P=0.19)$. Intubation was completed in these patients after administration of atracurium. There was no significant difference between groups with respect to mask ventilation and laryngoscopy scores. However there was a significant difference between the propofol group and the thiopentone and etomidate groups with respect to jaw relaxation $(P=0.018$ and $P=$ 0.006 , respectively). There was a significant difference between the propofol group and the etomidate group with respect to vocal cord position scores $(P=0.012$; Figure 1). Patient response (coughing or limb movement) after intubation and slow inflation of the endotracheal tube cuff in the three groups is shown in 


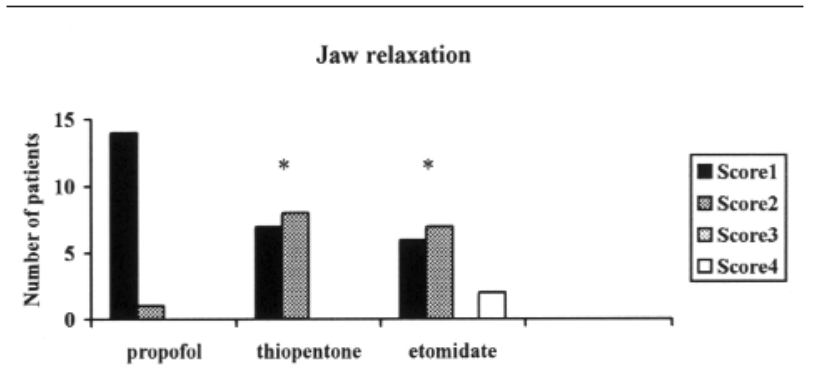

Laryngoscopy

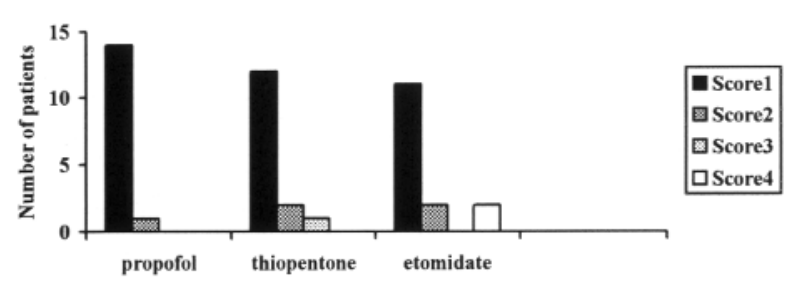

Vocal cords

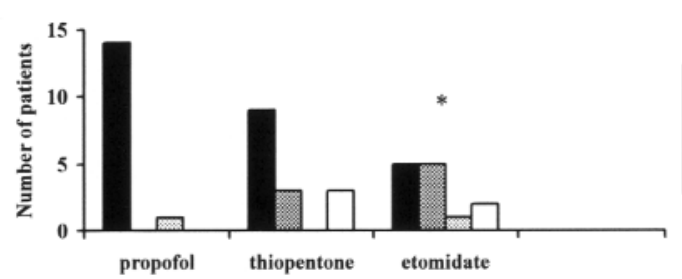

FIGURE 1 Score for jaw relaxation, laryngoscopy and vocal cord position before intubation. *Statistically significant difference compared to propofol group.

Figure 2. The three groups differed with respect to coughing $(P<0.001)$ and limb movement $(P=$ $0.003)$ after intubation. Coughing $(P<0.001)$ and limb movement $(P=0.003)$ after intubation was less severe with propofol compared to etomidate (Figure $2)$. Coughing $(P=0.027)$ after intubation was less severe with propofol compared to thiopentone (Figure 2). Etomidate and thiopentone groups were comparable with respect to intubating condition scores (Figures 1 and 2). Laryngoscopy and tracheal intubation were judged to be acceptable in $93.3 \%$, $66.7 \%$, and $40.0 \%$ of the patients in the propofol, thiopentone and etomidate groups, respectively. Overall intubating conditions were significantly better in the propofol group compared with the thiopentone and etomidate groups $(P<0.001$; Figure 3$)$.
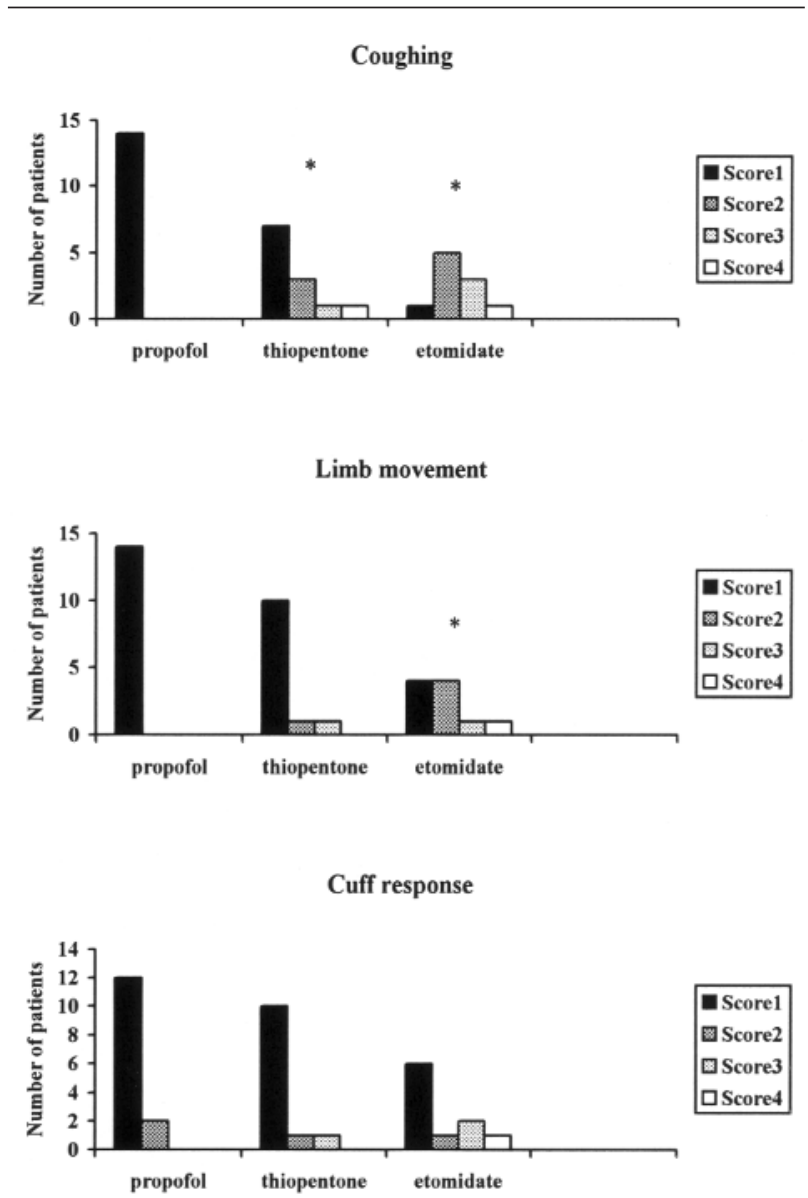

FIGURE 2 Score for patient response to intubation (coughing, limb movement) and slow (five-second) inflation of the endotracheal tube cuff. * Statistically significant difference compared to propofol goup.

Control MAP and HR were comparable between groups. MAP and HR changes differed between groups (Figure 4). MAP differed between the propofol and etomidate groups whereas HR differed between the thiopentone and propofol groups. MAP and HR changes varied with time and the time-group interaction was also significant, so the effect of time on each factor was evaluated separately. After anesthetic induction, the decrease in MAP was significant $(P<$ $0.05)$ in all groups. Compared to the baseline level, MAP values decreased throughout the investigation in the propofol group whereas MAP increased after intubation in the thiopentone and etomidate groups. After anesthetic induction, HR decreased significantly from the preinduction level $(P<0.05)$ in the propofol and etomidate groups. Compared to the baseline level, 


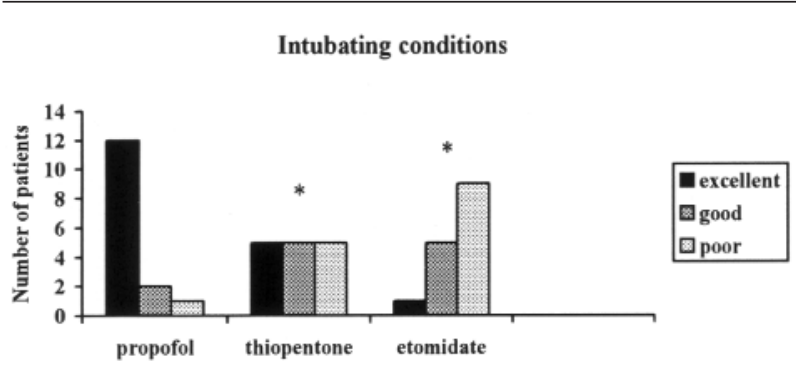

FIGURE 3 Overall intubating conditions. Excellent = all criteria scored as 1 (jaw relaxed, vocal cords open and no movement in response to intubation and cuff inflation); Good $=$ mask ventilation scored as 1 , and the other criteria as 1 or 2 ; Poor $=$ one of the criteria scored as 3 . *Statistically significant difference compared to propofol group.

HR decreased throughout the investigation in the propofol group. After intubation, HR increased in the etomidate group. No patient was treated for bradycardia or hypotension. Peripheral oxygen saturation remained at the preinduction level, $97-98 \%$, in all groups throughout the investigation.

\section{Discussion}

The results of this study suggest that remifentanil 3 $\mu \mathrm{g} \cdot \mathrm{kg}^{-1}$ administered with propofol $2 \mathrm{mg} \cdot \mathrm{kg}^{-1}$ provides good or excellent intubating conditions in $93.3 \%$ of premedicated patients with favourable airway anatomy. Thiopentone $6 \mathrm{mg} \cdot \mathrm{kg}^{-1}$ provided acceptable conditions in $66.7 \%$ of patients whereas etomidate 0.3 $\mathrm{mg} \cdot \mathrm{kg}^{-1}$ provided acceptable conditions in only $40.0 \%$ of patients. When laryngoscopy, intubation and skin incision are considered, tracheal intubation is the strongest stimulus. ${ }^{13}$ It is important to produce adequate conditions for laryngoscopy, but preventing subsequent coughing or response after tracheal intubation may be even more important. Excellent intubating conditions were achieved in $80 \%, 33.3 \%$ and $6.7 \%$ of patients in the propofol, thiopentone and etomidate groups respectively, suggesting thiopentone 6 $\mathrm{mg} \cdot \mathrm{kg}^{-1}$ and etomidate $0.3 \mathrm{mg} \cdot \mathrm{kg}^{-1}$ were inferior to propofol $2 \mathrm{mg} \cdot \mathrm{kg}^{-1}$ when combined with remifentanil $3 \mu \mathrm{g} \cdot \mathrm{kg}^{-1}$ in this regard.

Propofol $2.5 \mathrm{mg} \cdot \mathrm{kg}^{-1}$, thiopentone $5 \mathrm{mg} \cdot \mathrm{kg}^{-1}$ and etomidate $0.3 \mathrm{mg} \cdot \mathrm{kg}^{-1}$ are reported to be equipotent. ${ }^{14}$ The same dose ratio was used for propofol, thiopentone and etomidate in a recent study in which electroencephalogram (EEG) changes in relation to loss of consciousness were studied..$^{15}$ In another study
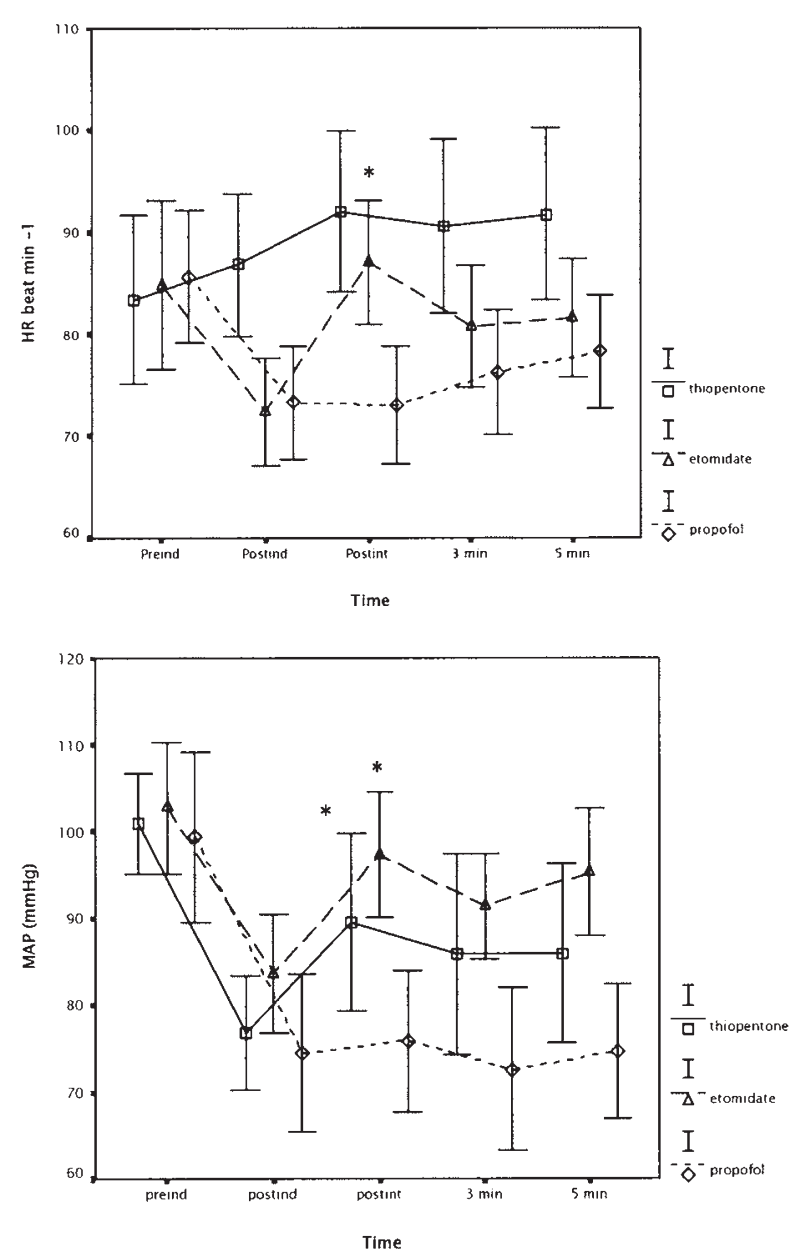

FIGURE 4 Heart rate (HR) and mean arterial pressure (MAP) responses to laryngoscopy and intubation; preind = baseline before atropine, postind $=45 \mathrm{sec}$ after bolus dose of hypnotic agent, postintubation $=$ immediately after intubation, $3 \mathrm{~min}=$ three $\mathrm{min}-$ utes after intubation; $5 \mathrm{~min}=$ five minutes after intubation. ${ }^{*}$ Within group significant changes compared to postinduction values.

comparing the effects of commonly used induction agents on cardiac index, the mean doses of induction agents were $2.24 \mathrm{mg} \cdot \mathrm{kg}^{-1}$ for propofol, $4.75 \mathrm{mg} \cdot \mathrm{kg}^{-1}$ for thiopentone and $0.29 \mathrm{mg} \cdot \mathrm{kg}^{-1}$ for etomidate. ${ }^{16}$ The loss of eyelash reflex was used as the endpoint for induction of anesthesia and the authors reported that the mean dose of induction agent used in each group correlated well with the doses that would be considered to be equipotent induction doses. ${ }^{16}$ In our study, the different potencies between drugs may have accounted for inter-group differences. Propofol resulted in better intubating conditions although a lower 
dose, compared with etomidate and thiopentone with respect to equipotency, was used. The doses of etomidate and thiopentone were not equipotent and could have masked an inter-group difference. The present findings suggest that thiopentone $6 \mathrm{mg} \cdot \mathrm{kg}^{-1}$ or etomidate $0.3 \mathrm{mg} \cdot \mathrm{kg}^{-1}$ have similar effects on intubating conditions in the absence of neuromuscular blockade. A retrospective power analysis revealed that a group size of approximately 35 patients in each group would have been required to identify a statistically significant difference between the thiopentone and etomidate groups with $80 \%$ power and $P=0.05$.

Inter-individual variability in response to thiopentone has been shown in previous studies. Avram et al. ${ }^{17}$ determined the combined effect of the patient-specific variables of age, sex, cardiac output, and either body weight or lean body mass on thiopentone requirements to reach the endpoint of loss of voluntary motor power, or the endpoint of EEG burst suppression. They confirmed a greater thiopentone potency in females and the progressive increase in thiopentone potency with age. Since both age and gender, or factors associated with them, contribute to the variability in the thiopentone dose required to reach both clinical and EEG endpoints, the same dose of thiopentone could have resulted in different intubating conditions in another population of patients compared with our male patients with an average age of $34 \mathrm{yr}$.

McKeating et al. ${ }^{18}$ investigated the depressant effects of induction doses of thiopentone and propofol on airway integrity and reactivity. They found that, when no muscle relaxants were given, laryngoscopy was easier to perform after propofol than after an equipotent dose of thiopentone, and that pharyngeal and laryngeal activity were more depressed after administration of propofol than after thiopentone. Using a fibreoptic laryngoscope, Barker et al. ${ }^{19}$ assessed vocal cord movement after induction of anesthesia with either propofol and thiopentone and observed that vocal cords adducted to a greater extent after induction of anesthesia with thiopentone than with propofol. More recently, Eames et al..$^{20}$ compared the effects of etomidate, propofol and thiopentone on respiratory resistance after tracheal intubation. Anesthesia was induced with either propofol $2.5 \mathrm{mg} \cdot \mathrm{kg}^{-1}$, thiopentone $5 \mathrm{mg} \cdot \mathrm{kg}^{-1}$ or etomidate $0.4 \mathrm{mg} \cdot \mathrm{kg}^{-1}$. Respiratory resistance after tracheal intubation was lower after induction with propofol than after induction with thiopental or with high-dose etomidate. In accordance with these results, we found that pharyngeal and laryngeal activity were more depressed after administration of propofol than after thiopentone or etomidate although we used a relatively low dose of propofol.
Hovarka et al. ${ }^{21}$ compared intubation without muscle relaxants after the induction of anesthesia with thiopentone $5 \mathrm{mg} \cdot \mathrm{kg}^{-1}$ or propofol $2.5 \mathrm{mg} \cdot \mathrm{kg}^{-1}$, supplemented with alfentanil $30 \mu \mathrm{g} \cdot \mathrm{kg}^{-1}$ and lidocaine 1.5 $\mathrm{mg} \cdot \mathrm{kg}^{-1}$ prior to administration of the hypnotic drug. In their study, groups did not differ from each other in regard to jaw tone, visualization of the larynx, and position of vocal cords. Endotracheal intubation was, however, easier after thiopentone $(P<0.05)$, but tolerance to the endotracheal tube was similar after both agents. The authors scored intubation as easy, intermediate, or difficult without using specific criteria. ${ }^{21}$ The discrepancy between Hovarka et al.'s results and ours may be related to the different scoring systems used.

Etomidate in combination with alfentanil for tracheal intubation without muscle relaxants has been evaluated by Stevens et al. ${ }^{3}$ They compared intubating conditions in premedicated patients given alfentanil $40 \mu \mathrm{g} \cdot \mathrm{kg}^{-1}$ followed by propofol $2 \mathrm{mg} \cdot \mathrm{kg}^{-1}$, thiopentone $4 \mathrm{mg} \cdot \mathrm{kg}^{-1}$, or etomidate $0.3 \mathrm{mg} \cdot \mathrm{kg}^{-1}$ and concluded that propofol $2 \mathrm{mg} \cdot \mathrm{kg}^{-1}$ or etomidate 0.3 $\mathrm{mg} \cdot \mathrm{kg}^{-1}$ were likely to provide adequate intubating conditions without muscle relaxants. ${ }^{3}$ MAP was more stable in patients who received etomidate compared with those who received propofol. ${ }^{3}$ In contrast, in our study etomidate appeared less likely to provide satisfactory intubating conditions. We also observed an increase in MAP and HR after intubation suggesting etomidate $0.3 \mathrm{mg} \cdot \mathrm{kg}^{-1}$ may not be suitable in this setting. Since thiopentone $4 \mathrm{mg} \cdot \mathrm{kg}^{-1}$ did not lead to satisfactory intubating conditions ${ }^{3}$, we used a higher dose of thiopentone to $6 \mathrm{mg} \cdot \mathrm{kg}^{-1}$ and obtained better results compared to those of Stevens et al. ${ }^{3}$ A higher dose of etomidate could have been used since 0.3 $\mathrm{mg} \cdot \mathrm{kg}^{-1}$ is in the mid-range with respect to the recommended induction dose for this drug. ${ }^{22}$ It should be noted that etomidate is used routinely in many countries. However, concerns regarding the temporary inhibition of steroid synthesis, even after a single dose curtailed its regulatory approval in Canada. Thiopentone provided the best hemodynamic conditions in our study. Since thiopentone $6 \mathrm{mg} \cdot \mathrm{kg}^{-1}$ is at the high end of the recommended dose range, ${ }^{22}$ we do not suggest using higher doses.

No patient was treated for bradycardia or hypotension in our study. Patients were prehydrated with saline $0.9 \% 7 \mathrm{~mL} \cdot \mathrm{kg}^{-1}$ before the induction of anesthesia and were given an anticholinergic agent. In the work by Thompson et al. ${ }^{23}$ in the absence of a concurrent vagolytic agent, remifentanil $1 \mu \mathrm{g} \cdot \mathrm{kg}^{-1}$ bolus over $30 \mathrm{sec}$ followed by an infusion of 0.5 $\mu \mathrm{g} \cdot \mathrm{kg}^{-1} \cdot \mathrm{min}^{-1}$ was associated with bradycardia or hypotension, or both, in five out of ten patients com- 
pared with one patient who received remifentanil and glycopyrrolate. Their results suggest pre-treatment with a vagolytic agent may be required before remifentanil if the incidence of bradycardia and hypotension is to be minimized. Klemola et al. ${ }^{6}$ considered that the administration of an anticholinergic agent is necessary, and contributed to the stability of HR observed in their study. Pretreatment with a vagolytic is often not necessary when lower doses of remifentanil are used. ${ }^{4,24}$

Based on its analgesic efficacy and its respiratory depressant effects, remifentanil is 20 to 30 times more potent than alfentanil after a single bolus dose. ${ }^{9}$ In a recent study Stevens and Wheatley ${ }^{5}$ showed that, when used in combination with propofol $2 \mathrm{mg} \cdot \mathrm{kg}^{-1}$, remifentanil $3-4 \mu \mathrm{g} \cdot \mathrm{kg}^{-1}$ provided satisfactory intubating conditions more reliably than remifentanil $1-2$ $\mu \mathrm{g} \cdot \mathrm{kg}^{-1}$. This is why we chose to give remifentanil 3 $\mu \mathrm{g} \cdot \mathrm{kg}^{-1}$ in combination with propofol $2 \mathrm{mg} \cdot \mathrm{kg}^{-1}$ in the present study. Thus our study and the study by Stevens et al. ${ }^{3}$ differ with respect to the dose of shortacting opioid since we used a higher dose of remifentanil compared to alfentanil.

The side effects of hypnotic agents (nausea and vomiting, pain on injection, myoclonic movements, and hiccups) during induction may interfere with the blinding procedure. We did not observe such side effects during induction and this observation may be attributed to premedication with midazolam, atropine and the coadministration of a potent opioid remifentanil, as well as the use of a large-bore venous access. ${ }^{11,25}$

This study was conducted in healthy young men, and the actual response might be quite different in another patient population. There are disadvantages and limitations to this technique which cannot be recommended for the elderly, compromised patients, or those with clinically significant cardiovascular or cerebrovascular disease. The decrease in arterial pressure might not be well tolerated in those less healthy patients. It should also be noted that tracheal intubation without neuromuscular blockade can be hazardous in some situations. If laryngoscopy and intubation are attempted under inadequate conditions, trauma to the airway or inadequate ventilation can result.

In conclusion, our results suggest that not all induction agents provide ideal conditions for laryngoscopy and tracheal intubation without muscle relaxants and that propofol $2 \mathrm{mg} \cdot \mathrm{kg}^{-1}$ is superior to thiopentone $6 \mathrm{mg} \cdot \mathrm{kg}^{-1}$ and etomidate $0.3 \mathrm{mg} \cdot \mathrm{kg}^{-1}$ when combined with remifentanil $3 \mu \mathrm{g} \cdot \mathrm{kg}^{-1}$. However propofol decreased arterial blood pressure during induction of anesthesia to a greater extent. Since a hypnotic agent having minimal effects on cardiovascu- lar function can be advantageous for patients in whom a decrease in arterial pressure may not be well tolerated, it will be of interest to investigate whether a larger dose of etomidate can improve intubating conditions when the use of neuromuscular blocking drugs is preferably avoided.

\section{References}

1 Scheller MS, Zornow MH, Saidman LJ. Tracheal intubation without the use of muscle relaxants: a technique using propofol and varying doses of alfentanil. Anesth Analg 1992; 75: 788-93.

2 Davidson JA, Gillespie JA. Tracheal intubation after induction of anaesthesia with propofol, alfentanil and i.v. lidocaine. Br J Anaesth 1993; 70: 163-6.

3 Stevens JB, Vescovo MV, Harris KC, Walker SC, Hickey $R$. Tracheal intubation using alfentanil and no muscle relaxant: is the choice of hypnotic important? Anesth Analg 1997; 84: 1222-6.

4 Grant S, Noble S, Woods A, Murdoch J, Davidson A. Assessment of intubating conditions in adults after induction with propofol and varying doses of remifentanil. Br J Anaesth 1998; 81: 540-3.

5 Stevens JB, Wheatley L. Tracheal intubation in ambulatory surgery patients: using remifentanil and propofol without muscle relaxants. Anesth Analg 1998; 86: 45-9.

6 Klemola UM, Mennander S, Saarnivaara L. Tracheal intubation without the use of muscle relaxants: remifentanil or alfentanil in combination with propofol. Acta Anaesthesiol Scand 2000; 44: 465-9.

7 Heier T, Steen PA. Awareness in anaesthesia: incidence, consequences and prevention. Acta Anaesthesiol Scand 1996; 40: 1073-86.

8 Ghoneim MM, Block RI. Learning and consciousness during general anesthesia. Anesthesiology 1992; 76 : 279-305.

9 Glass PSA, Hardman D, Kamiyama $\Upsilon$, et al. Preliminary pharmacokinetics and pharmacodynamics of an ultra-short-acting opioid: remifentanil (G187084B). Anesth Analg 1993; 77: 1031-40.

10 Egan TD, Minto CF, Hermann DJ, Barr J, Muir KT, Shafer SL. Remifentanil versus alfentanil: comparative pharmacokinetics and pharmacodynamics in healthy adult male volunteers. Anesthesiology 1996; 84: 821-33.

11 Reves JG, Glass PSA, Lubarsky DA. Nonbarbiturate intravenous anesthetics. In: Miller RD (Ed.). Anesthesia, fifth ed. Pennsylvania: Churchill Livingstone Inc., 2000: 228-72.

12 Mallampati SR, Gatt SP, Gugino LD, et al. A clinical sign to predict difficult tracheal intubation: a prospective study. Can Anaesth Soc J 1985; 32: 429-34. 
13 Kazama T, Ikeda K, Morita K. Reduction by fentanyl of the $\mathrm{C}_{\mathrm{P} 50}$ values of propofol and hemodynamic responses to various noxious stimuli. Anesthesiology 1997; 87: 213-27.

14 Gill RS, Scott RPF. Etomidate shortens the onset time of neuromuscular block. Br J Anaesth 1992; 69: 444-6.

15 Kuizenga K, Wierda JMK, Kalkman CJ. Biphasic EEG changes in relation to loss of consciousness during induction with thiopental, propofol, etomidate, midazolam or sevoflurane. Br J Anaesth 2001; 86: 354-60.

16 Price ML, Millar B, Grounds M, Cashman J. Changes in cardiac index and estimated sysemic vascular resisance during induction of anaesthesia with thiopentone, methohexitone, propofol and etomidate. $\mathrm{Br} \mathrm{J}$ Anaesth 1992; 69: 172-6.

17 Avram MJ, Sanghvi R, Henthorn TK, Krejcie TC. Determinants of thiopental induction dose requirements. Anesth Analg 1993; 76: 10-7.

18 McKeating K, Bali IM, Dundee JW. The effects of thiopentone and propofol on upper airway integrity. Anaesthesia 1988; 43: 638-40.

19 Barker P, Langton JA, Wilson IG, Smith G. Movements of the vocal cords on induction of anaesthesia with thiopentone or propofol. Br J Anaesth 1992; 69: 23-5.

20 Eames WO, Rooke GA, Wu RSC, Bishop MJ.

Comparison of the effects of etomidate, propofol, and thiopental on respiratory resistance after tracheal intubation. Anesthesiology 1996; 84: 1307-11.

21 Hovarka J, Honkavaara P, Korttila K. Tracheal intubation after induction of anaesthesia with thiopentone or propofol without muscle relaxants. Acta Anaesthesiol Scand 1991; 35: 326-8.

22 Morgan GA, Mikhail MS. Nonvolatile anesthetic agents. In: Morgan GA, Mikhail MS (Eds.).Clinical Anesthesiology, second ed., Stomford: Appleton \& Lange; 1996: 128-48.

23 Thompson JP, Hall AP, Russell J, Cagney B, Rowbotham $D J$. Effect of remifentanil on the haemodynamic response to orotracheal intubation. Br J Anaesth 1998; 80: 467-9.

24 Woods A, Grant S, Davidson A. Duration of apnoea with two different intubating doses of remifentanil. Eur J Anaesthesiol 1999; 16: 634-7.

25 Fragen RJ, Avram MJ. Barbiturates. In: Miller RD (Ed.). Anesthesia, fifth ed. Pennsylvania: Churchill Livingstone Inc.; 2000: 209-27. 